\title{
APLIKASI METODE INTERNAL MODEL CONTROL (IMC) 1 DEGREE OF FREEDOM (DOF) DALAM PENGENDALIAN SUHU PADA PROTOTYPE SISTEM HOT ROOM
}

\author{
Farsa Adhy Saktian ${ }^{*}$, Aris Triwiyatno, dan Sudjadi \\ Program Studi Sarjana Departemen Teknik Elektro, Universitas Diponegoro \\ Jl. Prof. Sudharto, SH, Kampus UNDIP Tembalang, Semarang 50275, Indonesia \\ ${ }^{*}$ E-mail: farsa.adhy@yahoo.com
}

\begin{abstract}
Abstrak
Metode kontrol yang digunakan pada hot room PT Hartono Istana Teknologi masih menggunakan metode kontrol onoff, serta suhu hot room yang dikendalikan menghasilkan keluaran yang tidak stabil dan susah mencapai referensi suhu yang diinginkan terlebih jika mendapat gangguan. Oleh karena itu dibutuhkan metode kontrol yang baik untuk menangani permasalahan kurang efektifnya metode kontrol pada kasus hot room PT HIT. Pada Penelitian ini dirancang mikrokontroler ATmega16 sebagai slave, kabel usb ttl sebagai media komunikasi antara master dan slave, serta slave berupa interface visual C\#. Metode kontrol yang digunakan untuk mengendalikan suhu pada prototype hot room adalah IMC 1 DOF. Hasil pengujian metode kontrol IMC 1 DOF terhadap 3 variasi referensi suhu, menghasilkan keluaran suhu yang mengikuti refrensi sesuai dengan variasi referensi suhu yang diberikan dengan nilai MSE 25,22 referensi tetap, nilai MSE 2,64 untuk referensi naik, dan MSE 1,17 untuk referensi turun serta sistem juga mampu mengikuti refrensi ke referensi suhu yang diinginkan meskipun diberi gangguan dengan waktu pemulihan menuju keadaan steadynya adalah 391 detik dan pada pengujian perbandingan metode kontrol IMC 1 DOF, PI, dan on-off diperoleh metode kontrol yang paling cocok untuk prototype sistem hot room adalah metode kontrol PI, karena secara keseluruhan memiliki kelebihan dibanding kontroler pembanding.
\end{abstract}

Kata Kunci: hot room, sensor suhu DS18B20, mikrokontroler ATmegal6, metode kontrol IMC 1 DOF.

\begin{abstract}
The control method used in PT Hartono Istana Teknologi's hot room is still using on-off control method, and the controlled hot room temperature produces unstable output and it is difficult to reach the desired temperature reference especially if it gets interrupted. Therefore, a good control method is needed to handle the problem of ineffective control method in PT HIT hot room case. In this final project designed by ATmega16 microcontroller as slave, usb ttl cable as communication medium between master and slave, and slave of visual interface C \#. The result of IMC 1 DOF control method test to 3 variation of temperature capable of producing temperature output following the reference according to variation of temperature reference given with MSE 25,22 for fixed reference, MSE 2, 64 for reference reference, and MSE value 1.17 for the reference down and the system is also capable of following the reference to the desired temperature reference although disturbed by the recovery time to the steady state is 391 seconds and on the comparison test of the IMC control method 1 DOF, PI and on-off obtained the most suitable control method for hot room prototype system is PI control method, because overall has many advantages compared to other controller.
\end{abstract}

Key words: hot room, temperature sensor DS18B20, ATmegal6 microcontroller, IMC 1 DOF.

\section{Pendahuluan}

Pada zaman moderen sekarang ini sistem kontrol di industri semakin berkembang pesat, terutama pada industri manufakturing membutuhkan kontroler yang baik sapaya dapat menunjang produktifitas dan efisiensi dalam proses produksi, akan tetapi masih banyak pengendalian suhu di industri yang kurang stabil dalam pengontrolan suhunya, salah satunya pada kasus pengendalian suhu hot room pada PT Hartono Istana Teknologi (PT HIT), terlebih jika mendapat gangguan berupa ambient temperature menyebabkan respon sistem lama dalam mencapai suhu yang diinginkan. Oleh karena itu dibutuhkan kontroler yang dapat mengendalikan suhu secara stabil untuk menangani permasalahan dalam pengendalian suhu pada kasus hot room PT HIT.

Banyak penelitian yang telah dilakukan dalam pengendalian suhu. Michael Abriyanto P L [1] melakukan penelitian mengenai sistem Supervisory Control And Data Aquisition (SCADA) dalam pengendalian suhu hot room menggunakan metode kontrol Proportional Integral PI 
dengan nilai parameter $\mathrm{Kp}=115$ dan $\mathrm{Ti}=33$ yang diperoleh melalui tuning Ziegler Nichols 1 hasil dari penelitian tersebut metode kontrol PI kurang stabil dan masih memiliki overshoot. Yudha Prasetyo [2] menggunakan metode Internal Model Control (IMC) 1 Degree Of Freedom (DOF) dan PID untuk mengendalikan suhu cairan pada heater, hasil penelitian tersebut menunjukkan bahwa metode kontrol IMC dengan epsilon (ع) 124,81 menghasilkan waktu naik, waktu penetapan, dan ITAE yang lebih kecil dibandingkan metode kontrol PID. Bayu Bagas Wara [3] menggunakan metode kontrol IMC 1 DOF pada plant First Order Plus Dead Time (FOPDT) hasil dari penelitian tersebut menunjukan bahwa kinerja kontrol IMC sesuai untuk plant FOPDT. Ayu La Haura,dkk [4] menggunakan metode kontrol IMC 1 DOF pada proses pengaturan suhu, hasil dari penelitian tersebut adalah kontrol IMC dapat merespon kenaikan ataupun penurunan suhu dengan nilai kenaikan 68,5 dan nilai penurunan 13,59. S.A Zulkeflee, dkk [5] menggunakan kontrol IMC dan kontrol Proportional Integral Derivative (PID) untuk mengatur temperature produksi polivinyl khlorida, hasil dari penelitian tersebut adalah IMC memiliki waktu penetapan yang lebih baik dari PID dan IMC lebih handal dalam mengurangi gangguan.

Pada Penelitian ini dirancang pengendalian suhu pada prototype hot room dengan menggunakan metode kontrol IMC 1 DOF.

Tujuan dari Penelitian ini adalah menerapkan metode kontrol IMC 1 DOF dalam pengendalian suhu pada prototype hot room.

\section{Metode \\ 2.1 Hot room}

Pada dunia industri hot room lebih dikenal dengan nama High Temperature Operating Life (HTOL) chamber atau high temperature chamber. HTOL merupakan tes keandalan (reliability) yang diterapkan pada komponen elektronik (solid state device) untuk mengetahui waktu hidup (life time) suatu komponen. Tes keandalan ini dilakukan dengan memberikan suhu tinggi terhadap komponen elektronik yang dioperasikan pada tegangan maksimum dengan jangka waktu yang telah ditentukan untuk mengetahui potensi kegagalan dan waktu hidup komponen terhadap pengaruh dari suhu tinggi yang diberikan [6]. Prosedur pengujian keandalan dan waktu hidup produk dalam hot room pada PT HIT sudah disesuaikan dengan standar military dan standar JEDEC yaitu sebagai berikut [7]:

1. Sebelum melakukan pengujian di hot room produk harus diuji dulu fungsinya pada suhu kamar.

2. Kondisi pengujian :

a. Jumlah produk yang akan diuji minimal 3 tipe yang berbeda.

b. Temperatur ruang yang harus dicapai dan diperbolehkan memiliki standar range temperatur $45^{\circ} \mathrm{C} \quad \pm 3{ }^{\circ} \mathrm{C}$ (standar yang digunakan PT HIT sesuai dengan suhu paling ekstrim di indonesia adalah $43^{\circ} \mathrm{C}$ ).

c. Kelembaban ruang adalah 35\% - 75\%. Kelembaban ruang tidak diatur dalam hot room PT HIT karena dianggap ruangan sudah memiliki kelembaban yang masuk dalam range.

d. Produk yang diuji harus dioperasikan dalam kondisi maksimum.

3. Waktu pengujian adalah 168 jam dengan spesifikasi 21 jam pengujian (hot room aktif bekerja) 3 jam istirahat (hot room berhenti bekerja) setiap harinya dalam 1 minggu.

4. Pengecekan sementara dilakukan ketika produk sedang diuji dan pengecekan keseluruhan dilakukan ketika waktu pengujian sudah terpenuhi.

\subsection{Perancangan Hardware Slave}

Slave pada Penelitian ini berupa mikrokontroler ATmega16 yang berfungsi untuk pembacaan data yang dikirimkan sensor, pemrosesan pengontrolan suhu hot room, pengiriman data sensor serta alarm ke slave, penerimaan data kontrol dari slave, dan pemrosesan alarm. Protokol Komunikasi One Wire1-wire merupakan salah satu protokol komunikasi yang dimiliki oleh ATmega16. 1-wire menggunakan 1 jalur data dan satu ground. [8]. Sensor suhu digital DS18B20 merupakan sensor suhu yang cukup akurat dan dapat diakses melalui One-Wire Bus Protokol (protokol komunikasi 1-wire), [9]Port yang digunakan oleh ATmega 16 untuk memenuhi fungsi fungsi tersebut adalah PORTA.1, PORTA.2, PORTA.3, PORTA.4, PORTA.5, PORTA.6, PORTB.0, PORTB.1, PORTB.2, PORTB.5, PORTB.6, PORTB.7, PORTC, PORTD.0, PORTD.1, PORTD.4, PORTD.5, PORTD.6, untuk lebih jelasnya dapat dilihat pada Gambar 1. 


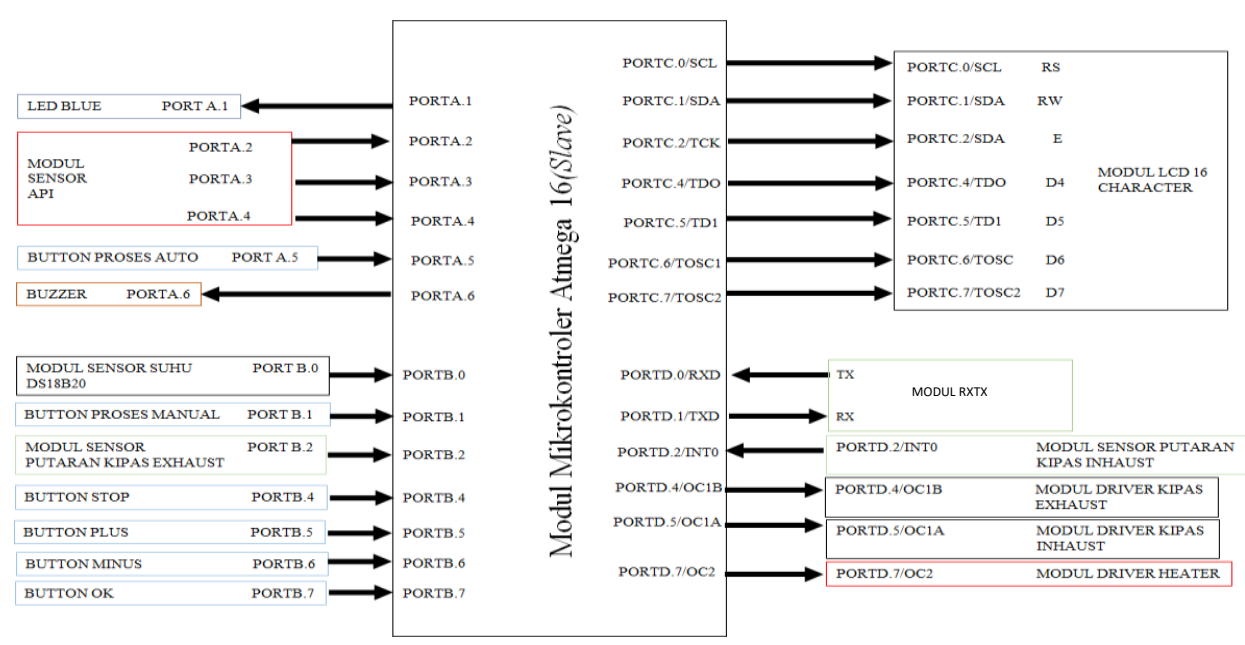

Gambar 1. Diagram perancangan slave beserta sensor.

\subsection{Perancangan Metode Kontrol IMC 1 DOF}

Dalam perancangan metode kontrol IMC 1 DOF dibutuhkan model prototype dari plant prototype hot room. Model dari plant prototype hot room sudah diperoleh melalui eksperimen bumptest yang dilakukan oleh [1], dengan persamaan model plant ditunjukan pada (1). Diagram blok kontrol IMC 1 DOF ditunjukkan pada Gambar 2.

$$
p^{\sim}(s)=\frac{0,419}{534 s+1} \cdot e^{-10 s}
$$

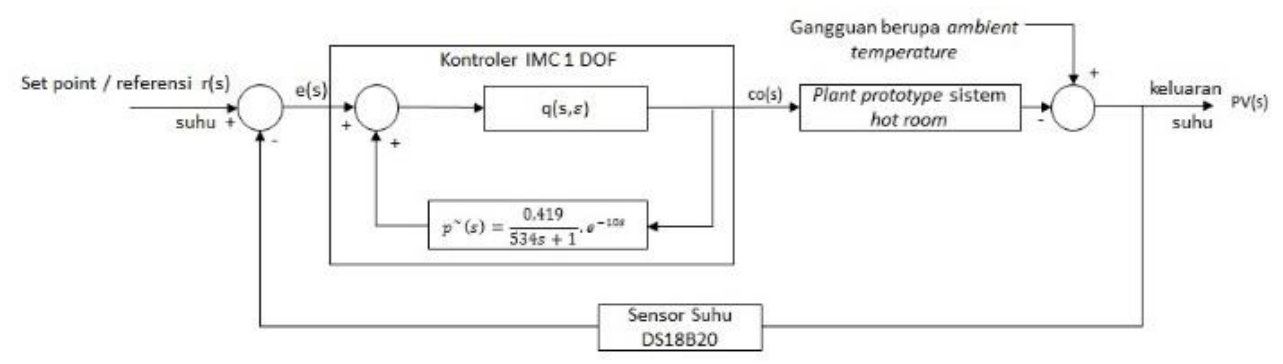

Gambar 2. Diagram Blok Kontrol IMC 1 DOF.

Berdasarkan persamaan 1 dapat di peroleh persamaan fungsi alih $\mathrm{q}(\mathrm{s}, \varepsilon)$ dengan menganggap model plant adalah representasi sempurna dari plant sebagai betikut:

$q(\mathrm{~s}, \varepsilon)=p^{\sim}(s)^{-1}=\frac{534 s+1}{0.419 .(\varepsilon s+1)}$

Sehingga dari persamaan model plant dan persamaan $\mathrm{q}(\mathrm{s}, \varepsilon)$ dapat diperoleh persamaan keluaran kontrol IMC 1 DOF.

$\operatorname{co}(s)=\frac{534 s+1}{0.419\left(\varepsilon s+1-e^{-10 s}\right)} \cdot e(s)$

Agar persamaan keluaran kontrol IMC 1 DOF dapat diolah oleh mikrokontroler maka persamaan keluaran kontrol tersebut harus dirubah dalam kawasan diskrit dengan cara mengubah persamaan keluaran kontroler IMC 1 DOF dalam kawasan waktu kontinyu seperti yang ditunjukan pada persamaan 2 .
$534 . \dot{e}(t)+e(t)=$

$\dot{c o}(t) \cdot 0.419 . \varepsilon \operatorname{co}(t) \cdot 0.419-0.419 . \operatorname{co}(t-10)$

Persamaan 1 dapat diubah ke kawasan waktu diskrit menggunakan metode backward difference, yang ditunjukan pada persamaan 3 .

$\left(\frac{534 . e(k)-534 . e(k-1)}{t s}\right)+\mathrm{e}(\mathrm{k})=\frac{0.419 \varepsilon \cdot \operatorname{co}(k)-0.419 . \operatorname{co}(k-1)}{t s}+$ $\operatorname{co}(k) .0 .419-0.419 \cdot \operatorname{co}(k-10)$

Sehingga persamaan keluaran kontrol IMC 1 DOF dalam kawasan waktu diskrit ditunjukan pada persamaan 4.

$\operatorname{co}(\mathrm{k})=\frac{e(k) \cdot(534+t s)}{0.419 \cdot \varepsilon+0.419 \cdot t s}-\frac{534 \cdot e(k-1)}{0.419 \cdot \varepsilon+0.419 \cdot t s}+\frac{0.419 \cdot \varepsilon \cdot \operatorname{co}(k-1)}{0.419 \cdot \varepsilon+0.419 \cdot t s}+$ $0.419 . c o(k-10) . t s$

$0.419 . \varepsilon+0.419 . t s$

Dari persamaan 4 terdapat nilai $\varepsilon$, nilai $\varepsilon$ tersebut diperoleleh berdasarkan metode rivera dengan nilai $\mathrm{L}=10$ sebagai berikut : $\varepsilon>8$

Untuk mendapatakan nilai $\varepsilon$ terbaik dilakukan percobaan trial and error dengan 10 variasi nilai $\varepsilon$. 
Tabel 1 Percobaan trial and error nilai $\varepsilon$.

\begin{tabular}{cc}
\hline Epsilon $(\varepsilon)$ & MSE \\
\hline 13 & 21.274 \\
13.5 & 21.610 \\
14 & 20.805 \\
14.5 & 22.081 \\
15 & 20.485 \\
15.5 & 21.854 \\
16 & 21.883 \\
16.5 & 23.194 \\
17 & 22.807 \\
17.5 & 23.031 \\
\hline
\end{tabular}

Berdasarkan tabel 1 dapat dilihat bahwa nilai $\varepsilon$ yang memliki nilai MSE paling kecil adalah $\varepsilon 15$ dengan nilai MSE sebesar 20.485, sehingga nilai $\varepsilon 15$ yang dipilih pada Penelitian ini. Mean Square Error(MSE) adalah sebuah respons sistem dapat digunakan untuk mengamati baik atau tidaknya respons sistem. MSE adalah rata-rata dari jumlah muthlak selisih antara referensi dengan keluaran proses (galat) yang dikuadratkan, dimulai dari $\mathrm{t}=0$ hingga $\mathrm{t}$ yang ditentukan sehingga semakin kecil galat yang dihasilkan dari suatu respons sistem maka semakin kecil pula MSE ini berarti semakin baik respons sistem dalam mengikuti referensi. Formula MSE untuk ditunjukkan pada Persamaan 2.19 [10].

$\frac{1}{n} \sum_{t=0}^{t=n}\left(\left|r_{t}-y_{t}\right|\right)^{2}$

Di mana :

$\mathrm{n}=$ Banyaknya data yang diamati.

$r_{t}=$ Referensi pada saat detik ke $\mathrm{t}$

$y_{t}=$ Respon keluaran sistem pada saat detik ke $\mathrm{t}$

\subsection{Perancangan Software}

Algoritma dan diagram alir keseluruhan pada Penelitian ini dapat dibagi menjadi dua bagian yaitu sebagai berikut :
1. Slave

Pada bagian slave terdiri dari algoritma dan diagram alir dari slave yang ditunjukkan pada Gambar 3 . Algoritma perangkat lunak dari slave adalah sebagai berikut :

a. Mulai.

b. Inisialisasi I/O register dan variabel.

c. Deteksi dan inisialisasi sensor DS18B20,

d. Tampilan LCD "FARSA ADHY SAKTIAN 21060113130142”.

e. Proses off (proses close loop atau open loop tidak dijalankan).

f. Proses penentuan mode operasi yang akan dijalankan dengan algoritma sebagai berikut :

- Jika diterima perintah proses auto dari interface maka lanjutkan ke algoritma g, jika tidak lanjutkan ke poin 2.

- Jika diterima perintah proses manual dari interface maka lanjutkan ke algoritma j, jika tidak lanjutkan ke poin 3.

- Pemilihan mode operasi melalui tombol pada kontrol panel di slave. Jika tombol start auto ditekan maka lanjutkan ke algoritma h, jika tombol start manual ditekan maka lanjutkan ke algoritma $\mathrm{k}$.

g. Proses penerimaan data parameter kontrol close loop (setpoint) dari interface.

h. Proses penentuan data parameter kontrol close loop (setpoint) melalui tombol pada kontrol panel di slave.

i. Proses close loop.

j. Proses penerimaan data parameter kontrol open loop (CO) dari interface.

k. Proses penentuan data CO pada kontrol open loop melalui tombol pada kontrol panel di slave.

1. Proses open loop.

m. Selesai.

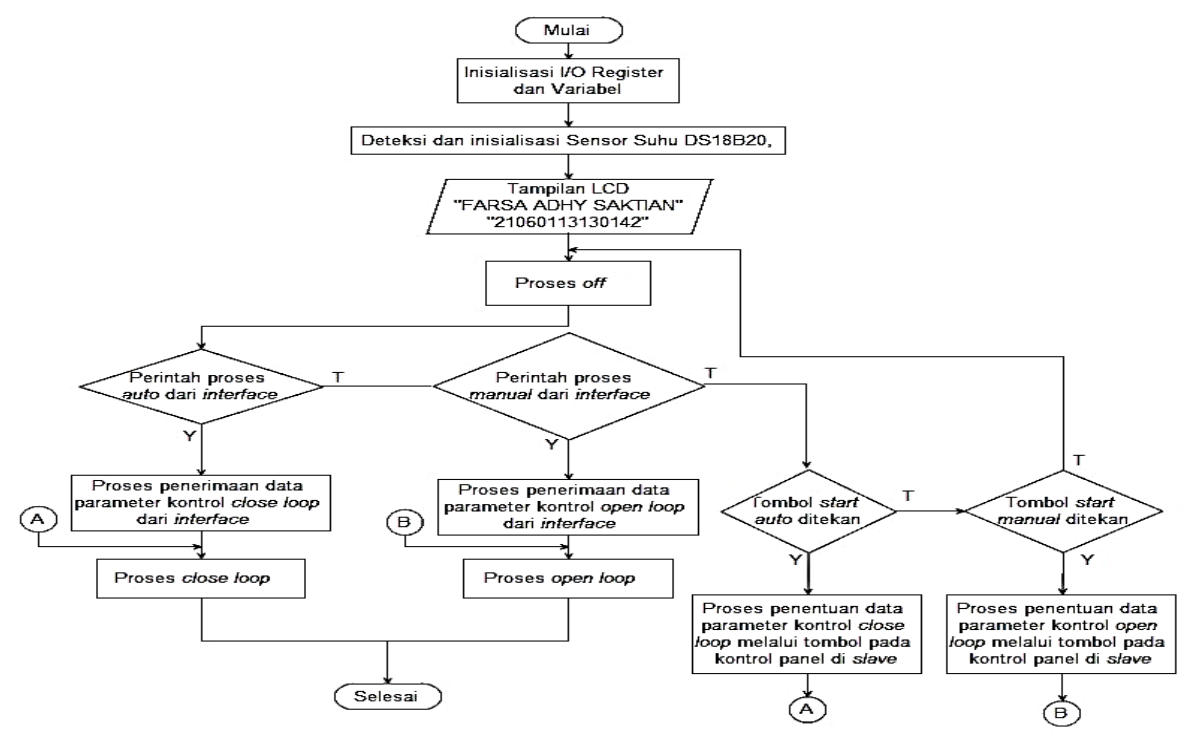

Gambar 3. Diagram Alir Keseluruhan dari Slave 


\section{Master}

Pada bagian master terdiri dari algoritma dan diagram alir dari master yang ditunjukkan pada Gambar 4 Algoritma perangkat lunak dari master adalah sebagai berikut :

a. Mulai.

b. Tampilan form login interface.

c. Masukkan username dan password. Jika username dan password salah maka akan dimunculkan peringatan username atau password salah, jika username = "ADMINHR" dan password = "ADMINHR" maka lanjut ke algoritma d.

d. Masuk ke tampilan menu utama, jika dipilih process auto maka maka masuk mode close loop, jika dipilih process manual maka masuk mode open loop, jika dipilih logout maka kembali ke tampilan form login, jika tidak maka kembali ke tampilan mеnи utama.

e. Selesai.

Berdasarkan algoritma master keseluruhan dapat disusun diagram alir dari bagian master dapat ditunjukkan pada Gambar 4.

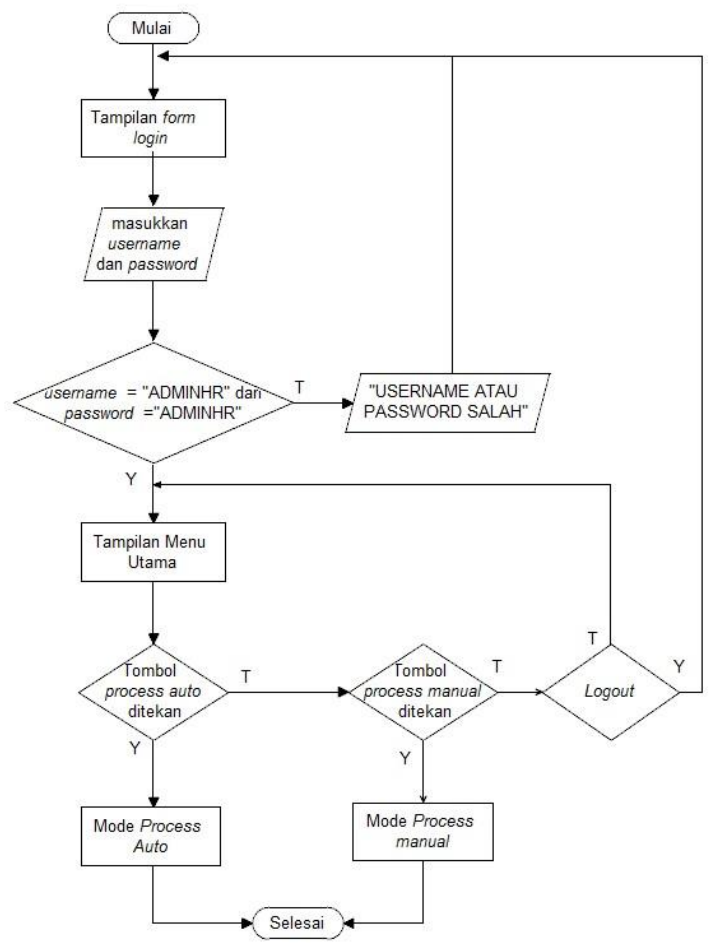

Gambar 4. Diagram Alir Keseluruhan dari Master.

\subsection{Perancangan Form Login}

Form login pada perancangan software master berfungsi sebagai salah satu syarat agar user dapat membuka tampilan interface. Form login diperlukan untuk keamanan dari interface sehingga hanya user yang memiliki username dan password yang dapat mengakses interface.

\subsection{Perancangan interface}

Interface pada Penelitian ini digunakan sebagai antarmuka antara user dan plant protoype hot room. Interface digunakan untuk menampilkan informasi kinerja plant yang dikirimkan oleh slave baik dalam bentuk numerik maupun grafik. Selain memberikan informasi mengenai plant pada user, user juga dapat melakukan pengendalian terhadap plant melalui interface. Perancangan interface terbagi menjadi 3 bagian yaitu interface menu utama, interface process auto, dan interface process manual.

1. Perancangan interface menu utama

Interface menu utama dapat diakses setelah user login. Gambar 5 menunjukkan tampilan Interface menu utama.

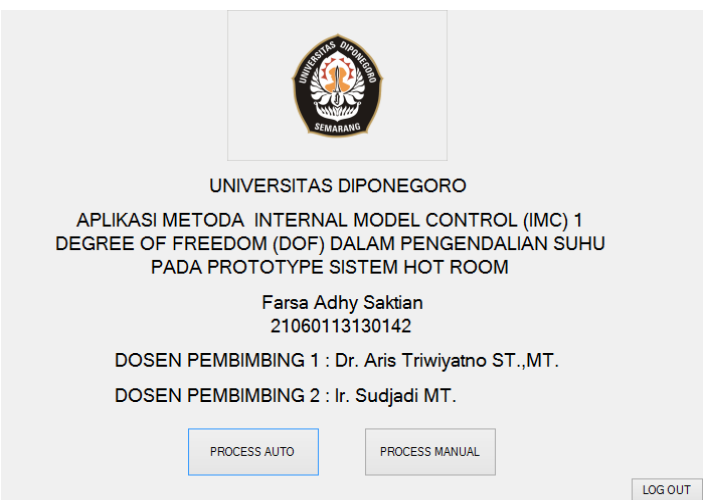

Gambar 5. Tampilan interface menu utama.

2. Perancangan interface process auto Interface process auto dapat diakses ketika tombol pada process auto ditekan. Gambar 6 menunjukkan tampilan Interface process auto.

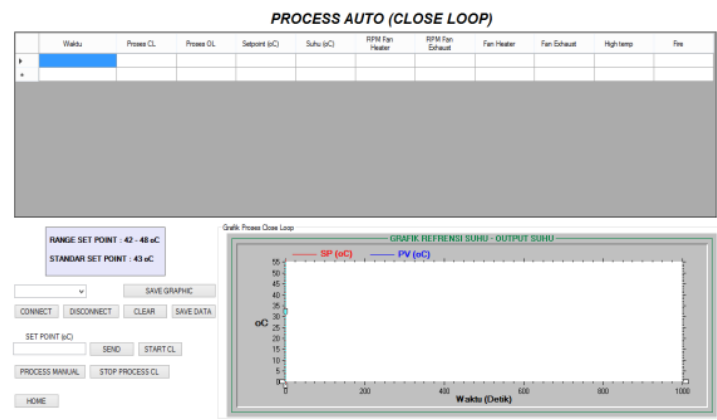

Gambar 6. Tampilan interface process aut 
3. Perancangan interface process manual

Interface process manual dapat diakses ketika tombol pada process manual ditekan. Tampilan interface process manual menyerupai tampilan interface process auto hanya terdapat perbedaan tampilan tabel pada kolom setpoint diganti dengan $\mathrm{CO}$ dan tombol startcl menjadi start ol serta tombol process manual menjadi process auto.

\section{Hasil dan Analisa \\ 3.1. Pengujian Slave \\ 3.1.1. Pengujian Sensor DS18B20}

Pengujian pembacaan sensor DS18B20 dilakukan dengan membandingkan pembacaan suhu antara sensor DS18B20 dengan termometer digital. Hasil pengujian sensor suhu DS18B20 ditunjukkan pada Tabel 2.

Tabel 2. Pengujian Sensor Suhu DS18B20.

\begin{tabular}{cccc}
\hline No. & $\begin{array}{c}\text { Sensor DS18B20 } \\
\left({ }^{\circ} \mathbf{C}\right)\end{array}$ & $\begin{array}{c}\text { Suhu Termometer } \\
\left({ }^{\circ} \mathbf{C}\right)\end{array}$ & $\begin{array}{c}\mid \text { Error } \\
\left({ }^{\mathbf{0}} \mathbf{C}\right)\end{array}$ \\
\hline 1 & 26.56 & 26.9 & 0.34 \\
2 & 27.75 & 28.2 & 0.5 \\
3 & 28.37 & 28.8 & 0.43 \\
4 & 31.87 & 32.3 & 0.43 \\
5 & 33.06 & 33.6 & 0.54 \\
6 & 43 & 43.5 & 0.5 \\
7 & 45 & 45.6 & 0.6 \\
8 & 47.44 & 47.6 & 0.16 \\
9 & 47.87 & 48.4 & 0.53 \\
10 & 48 & 48.6 & 0.6 \\
& Rata-rata error & & 0.463 \\
\hline
\end{tabular}

Berdasarkan hasil pengujian sensor suhu DS18B20 pada Tabel 2, dapat dilihat bahwa pembacaan suhu oleh sensor DS18B20 cukup akurat dengan rata-rata error pembacaan suhu adalah $0.463^{\circ} \mathrm{C}$. Perbedaan pembacaan suhu pada pengujian dapat disebabkan karena sensor suhu DS18B20 memiliki akurasi $\pm 0,5^{\circ} \mathrm{C}$ antara suhu $-10^{\circ} \mathrm{C}$ hingga $65^{\circ} \mathrm{C}$ dan termometer digital hanya dapat menampilkan data suhu hingga 1 angka dibelakang koma.

\subsubsection{Pengujian Sensor Putaran}

Pengujian pembacaan sensor putaran dilakukan dengan membandingkan pembacaan putaran kipas antara sensor putaran dan RPM meter digital. Hasil dari pengujian sensor putaran ditunjukkan pada Tabel 3.

Tabel 3. Pengujian Sensor Putaran.

\begin{tabular}{cccc}
\hline No. & $\begin{array}{c}\text { RPM Meter Digital } \\
\text { (RPM) }\end{array}$ & $\begin{array}{c}\text { Sensor Putaran } \\
\text { (RPM) }\end{array}$ & $\begin{array}{c}\mid \text { Error } \\
\text { (RPM) }\end{array}$ \\
\hline 1 & 939,9 & 940 & 0,1 \\
2 & 1446 & 1440 & 6 \\
3 & 1839 & 1840 & 1 \\
4 & 2043 & 2040 & 3 \\
5 & 2220 & 2220 & 0 \\
6 & 2292 & 2300 & 8 \\
7 & 2348 & 2340 & 8 \\
8 & 2412 & 2420 & 8 \\
9 & 2454 & 2460 & 6 \\
10 & 2484 & 2480 & 6 \\
& Rata-rata error & & 4,61 \\
\hline
\end{tabular}

Berdasarkan hasil pengujian pembacaan sensor putaran pada Tabel 3, dapat dilihat bahwa pembacaan putaran oleh sensor putaran memiliki akurasi yang cukup baik dengan rata-rata error pembacaan putaran kipas adalah 4,61 RPM.

\subsection{Pengujian Master \\ 3.3.1. Pengujian Sistem Login}

Pengujian sistem login dilakukan dengan mengisikkan username dan password yang salah dan sesuai dengan level user. Dari hasil pengujian sistem login hanya user yang memiliki username dan password yang dapat mengakses tampilan interface.

\subsubsection{Pengujian Sistem Pengawasan dan Alarm pada master.}

Pengujian alarm dapat dibagi menjadi 5 bagian yaitu pengujian kondisi safe, pengujian alarm kipas heater, pengujian alarm kipas exhaust, pengujian alarm high temperature, pengujian alarm api. Berdasarkan hasil pengujian sistem pengawasan dan alarm pada interface data kinerja plant dapat dikirimkan dengan baik dan dapat ditampilkan pada interface, jika terindikasi kondisi alarm maka interface akan menampilkan tanda alarm berupa tulisan alarm dan buzzer.

\subsection{Pengujian Respon Sistem 3.4.1. Pengujian Respon Open Loop}

Pengujian respon sistem open loop dilakukan untuk mengetahui karakteristik dari prototype hot room yang akan dikendalikan suhunya. Pengujian ini dilakukan dengan mengatur mode operasi ke operasi manual dan memberikan sinyal CO $100 \%$ ditunggu hingga keadaan steady state. Hasil dari pengujian respon sistem open loop ditunjukkan pada Gambar 7.

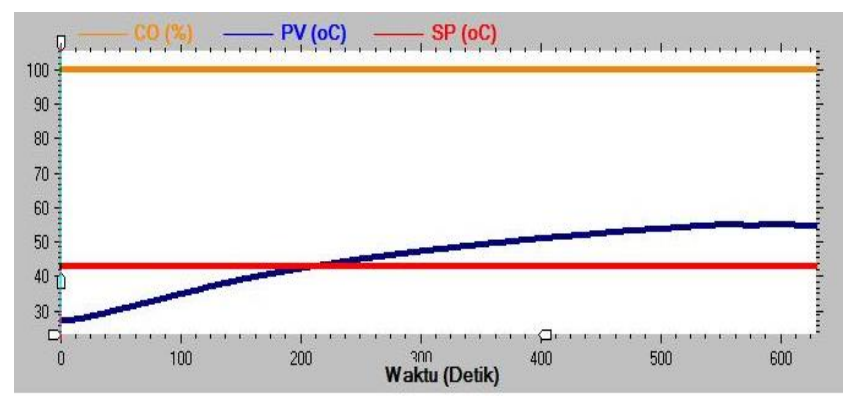

Gambar 7. Hasil dari respon sistem openloop nilai CO $100 \%$.

Berdasarkan hasil pengujian respon sistem open loop yang terdapat pada Gambar 7 dapat dilihat bahwa suhu akan meningkat seiring dengan meningkatnya sinyal CO yang diberikan akan tetapi suhu tidak akan meningkat terus menerus dan akan stabil pada suhu tertentu. Hal ini menunjukkan bahwa output suhu yang dihasilkan oleh plant memiliki model self regulating (FOPDT). Keluaran 
dari sistem openloop tidak dapat mencapai dan mengikuti setpoint, hal itu dikarenakan sistem openloop tidak memiliki umpan balik ataupun kontroler.

\subsubsection{Pengujian Respon Sistem dengan Referensi Tetap}

Pengujian respon sistem dengan referensi tetap dilakukan dengan mengirimkan referensi suhu sebesar $43^{\circ} \mathrm{C}$ melalui interface. Pengujian ini dilakukan pada kondisi suhu awal prototype hot room $28,25^{\circ} \mathrm{C}$. Respon yang dihasilkan sistem dengan referensi tetap ditunjukkan pada Gambar 9. Dari pengujian ini dapat diketahui kemampuan kontrol IMC 1 DOF dalam merespon error yang terjadi antara referensi suhu dan keluaran suhu untuk mencapai dan mempertahankan referensi suhu yang tetap.

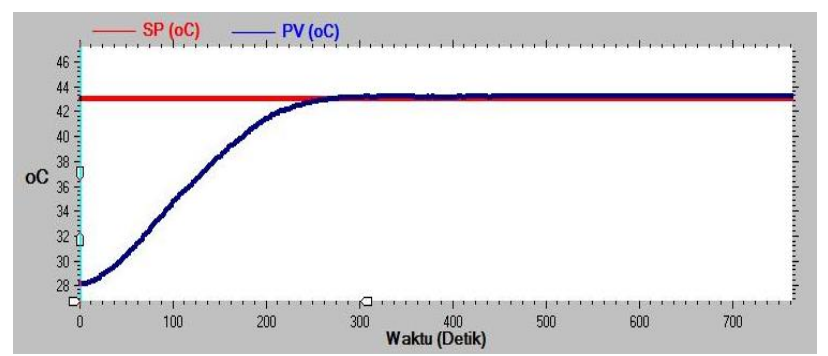

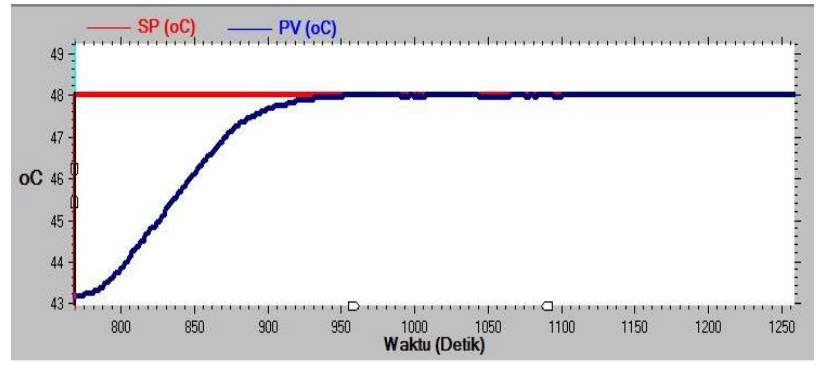

Gambar 9. Hasil pengujian respon sistem dengan referensi naik.

Berdasarkan hasil respon sistem pada referensi naik pada Gambar 9 dapat dilihat bahwa kontrol IMC 1 DOF mampu mencapai dan mempertahankan output suhu sesuai dengan kenaikan referensi suhu menjadi $48^{\circ} \mathrm{C}$ dengan tanggapan respon transien untuk Td sebesar 63 detik, Tr sebesar 69 detik, Ts sebesar 332 detik, Mp adalah $0 \%\left(0,0^{\circ} \mathrm{C}\right)$ dan nilai MSE yang diperoleh adalah 2,46. Dari hasil pengujian respon sistem dengan referensi naik dapat disimpulkan bahwa kontrol IMC 1 DOF mampu bekerja dengan baik dalam mencapai dan mempertahankan kenaikan referensi suhu menjadi $48^{\circ} \mathrm{C}$ meskipun respon yang dihasilkan sering berosilasi namun akhirnya dapat mencapai kondisi steady di titik $48^{\circ} \mathrm{C}$.

\subsubsection{Pengujian Respon Sistem dengan Referensi Turun}

Pengujian respon sistem dengan referensi turun dilakukan dengan mengubah referensi suhu dari $48^{\circ} \mathrm{C}$ turun menjadi $42^{\circ} \mathrm{C}$. dengan kondisi suhu awal pada prototype hot room adalah $48^{\circ} \mathrm{C}$. Pengujian ini dilakukan untuk mengetahui kemampuan kontrol IMC 1 DOF dalam menanggapi penurunan referensi suhu. Hasil pengujian respon sistem dengan referensi turun ditunjukkan pada Gambar 10.

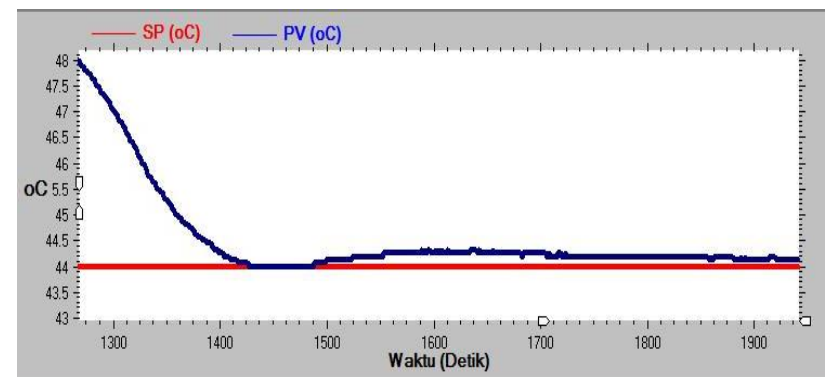

Gambar 10. Hasil pengujian respon sistem dengan referensi turun.

Berdasarkan hasil respon sistem pada referensi naik pada Gambar 10 dapat dilihat bahwa kontrol IMC 1 DOF mampu mencapai dan mempertahankan output suhu sesuai dengan penurunan referensi menjadi $44^{\circ} \mathrm{C}$ dengan tanggapan respon transien untuk Td sebesar 65 detik, $\mathrm{Tr}$ sebesar 166 detik, Tp sebesar 327 detik, Ts sebesar 395 detik, Mp adalah $0,70 \%\left(0,31^{\circ} \mathrm{C}\right)$ dan nilai MSE yang diperoleh adalah 1,17. Dari hasil pengujian respon sistem 
dengan referensi turun dapat disimpulkan bahwa kontrol IMC 1 DOF mampu bekerja dengan baik dalam mencapai penurunan referensi suhu menjadi $44^{\circ} \mathrm{C}$, akan tetapi memiliki error steady state $0.12^{\circ} \mathrm{C}$ hal ini disebabkan suhu udara luar yang berubah ubah, dan respon yang dihasilkan memiliki Mp yang cukup besar.

\subsubsection{Pengujian Respon Sistem dengan Gangguan}

Pengujian respon sistem dengan gangguan dilakukan dengan membuka pintu hot room selama 10 menit ketika sistem telah mencapai keadaan stabil. Pengujian ini dilakukan untuk mengetahui kemampuan kontrol IMC 1 DOF dalam merespon gangguan tersebut. Pengujian ini dilakukan pada kondisi referensi suhu yang diberikan adalah $43^{\circ} \mathrm{C}$, suhu prototype hot room sebelum diberi gangguan adalah stabil pada suhu $43^{\circ} \mathrm{C}$. Hasil pengujian respon sistem dengan gangguan ditunjukkan pada Gambar 11.

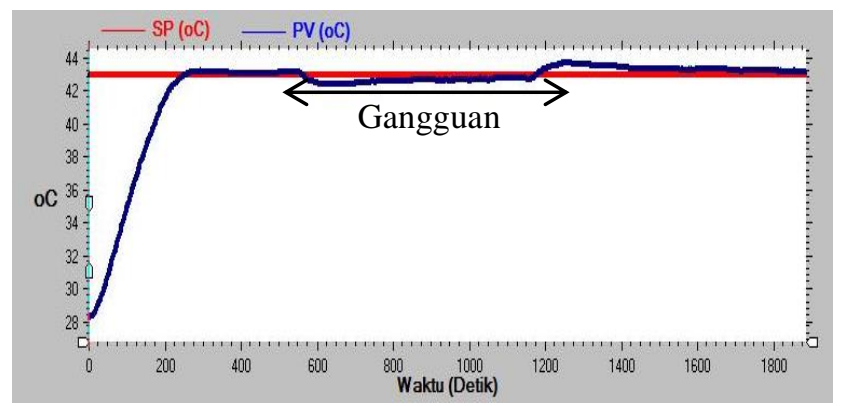

\section{Gambar 11. Hasil pengujian respon sistem dengan gangguan.}

Berdasarkan hasil respon sistem dengan gangguan pada Gambar 11 dapat dilihat bahwa gangguan diberikan pada waktu 02:38:55 selama kurang lebih 10 menit, karena efek gangguan respon sistem menjadi tidak stabil dan suhu menurun cukup jauh dari referensi $43^{\circ} \mathrm{C}$ dengan suhu terendah yang tercapai adalah $42,37^{\circ} \mathrm{C}$, akan tetapi suhu tidak terus menurun pada waktu 02:49:04 suhu mulai berangsur naik hingga suhu tertinggi $42,75^{\circ} \mathrm{C}$ tetapi sistem tetap tidak dapat mencapai referensi suhu $43^{\circ} \mathrm{C}$ dan masih tidak stabil, kemudian pada waktu 02:49:51 pintu prototype hot room ditutup kembali dan suhu mulai berangsur naik untuk mencapai referensi yang diberikan. Dari hasil pengujian respon sistem dengan gangguan dapat disimpulkan bahwa kontrol IMC 1 DOF mampu bekerja dengan baik dalam menanggapi gangguan yang diberikan sehingga gangguan dapat dikurangi dan respon sistem dapat mengikuti referensi $43^{\circ} \mathrm{C}$, dengan waktu pemulihan menuju keadaan steadynya adalah 391 detik.

\subsubsection{Pengujian Perbandingan Metode Kontrol IMC 1 DOF, Metode Kontrol PI, Metode Kontrol On Off}

Pengujian perbandingan Kontroler dilakukan dengan membandingkan respon keluaran sistem metode kontrol
IMC 1 DOF, metode kontrol PI, dan metode kontrol on off. Suhu awal metode kontrol IMC 1 DOF adalah 28.31, suhu awal metode kontrol PI adalah 28.25 dan suhu awal metode kontrol on off adalah 28.62. Hasil perbandingan pengujian metode kontrol IMC 1 DOF, Kontrol Proportional Integral (PI), Kontrol on off ditunjukan pada tabel 4.

Tabel 4. Hasil pengujian Perbandingan respon keluaran sistem metode kontrol IMC 1 DOF, PI, ON OFF .

\begin{tabular}{ccccccc}
\hline Metode & $\mathrm{Td}(\mathrm{s})$ & $\mathrm{Tr}(\mathrm{s})$ & $\mathrm{Tp}(\mathrm{s})$ & $\mathrm{Ts}(\mathrm{s})$ & $\mathrm{Mp}(\%)$ & $\mathrm{MSE}$ \\
\hline $\begin{array}{c}\text { IMC 1 } \\
\text { DOF }\end{array}$ & 125 & 269 & 602 & 379 & 0.58 & 25,22 \\
$\mathrm{PI}$ & 106 & 217 & 242 & 440 & 0.86 & 22,51 \\
ON OFF & 112 & 227 & 231 & - & 0.58 & 22,70 \\
\hline
\end{tabular}

Metode kontrol IMC 1 DOF memiliki kelebihan dibanding metode kontrol PI maupun metode kontrol on off, yaitu memiliki waktu penetapan (Ts), dan maximum overshoot (Mp) yang lebih kecil dari pada metode kontrol pembanding, akan tetapi nilai rise time (Tr), waktu tunda (Td), dan nilai MSE metode kontrol PI lebih baik dari metode pembanding, namun nilai peak time ( $\mathrm{Tp}$ ) metode kontrol on off lebih baik daripada metode kontrol PI maupun metode kontrol IMC 1 DOF. Dapat diambil kesimpulan bahwa metode kontrol yang paling cocok untuk prototye sistem hot room adalah metode kontrol PI, karena secara keseluruhan memiliki banyak kelebihan dibanding kontroler pembanding.

\section{Kesimpulan}

Berdasarkan pengujian dan analisis yang dilakukan pada aplikasi metode IMC 1 DOF dalam pengendalian suhu pada prototype hot room, aplikasi metode kontrol IMC 1 DOF dalam pengendalian suhu pada prototype hot room telah berhasil dibuat dengan prosentase keberhasian $95 \%$. Pada pengujian sensor DS18B20 dihasilkan rata-rata error pembacaan suhu adalah $0,463^{\circ} \mathrm{C}$. Pada Pengujian master, sistem login dan alarm pada master sudah dapat berjalan dengan baik. Pada pengujian respon sistem dengan referensi tetap, metode kontrol IMC 1 DOF menghasilkan Td sebesar 125 detik, Tr sebesar 269 detik, Tp sebesar 602 detik, Ts sebesar 279 detik, Mp adalah sebesar 0,58\% $\left(0,25^{\circ} \mathrm{C}\right)$ dan nilai MSE yang dihasilkan sebesar 25,22. Pada pengujian respon sistem dengan referensi naik, metode kontrol IMC 1 DOF menghasilkan Td sebesar 69 detik, Tr sebesar 180 detik, Ts sebesar 332 detik, dan nilai MSE yang dihasilkan sebesar 2,46. Pada pengujian respon sistem dengan referensi turun, metode kontrol IMC 1 DOF menghasilkan Td sebesar 65 detik, Tr sebesar 180 detik, Tp sebesar 327 detik, Ts sebesar 395 detik, Mp adalah sebesar $0,70 \%\left(0,31^{\circ} \mathrm{C}\right)$ dan nilai MSE yang dihasilkan sebesar 1,17. Dari hasil pengujian perbandingan metode kontrol, kontroler yang paling cocok untuk prototye sistem hot room adalah metode kontrol PI, karena secara keseluruhan 
memiliki banyak kelebihan dibanding kontroler pembanding.

\section{Referensi}

[1] M. A. Limantara, "PERANCANGAN SISTEM SUPERVISORY CONTROL AND DATA ACQUISITION (SCADA) DALAM PENGENDALIAN SUHU PADA PROTOTYPE HOT ROOM," 2017.

[2] Y. Prasetyo, I. Setiawan, and B. Setiyono, "APLIKASI METODE INTERNAL MODEL CONTROL ( IMC ) ONE DEGREE OF FREEDOM ( 1 DOF ) UNTUK PENGENDALIAN SUHU CAIRAN PADA HEATER," no. Imc, pp. 1-7.

[3] B. B. Wara, "KINERJA KONTROLER INTERNAL MODEL KONTROL ( IMC ) PADA PLANT FIRST ORDE PLUS DEAD TIME ( FOPDT )," no. Imc.
[4] A. La Haura, K. Qanitatun, and J. P. Sutikno, "Rerefinery Used Oil Vacuum Distillation Column Control by using Internal Model Control," vol. 56, pp. 1471$1476,2017$.

[5] S. a Zulkeflee, N. Aziz, C. K. Chan, E. Campus, S. Ampangan, and N. Tebal, "Temperature Control in Polyvinyl Chloride Production : Internal Model Control ( IMC ) and Proportional, Integral and Derivative ( PID ) controller Implementation," no. Imc, pp. 805-811, 2007.

[6] D. Hanan, Considerations for effective high temperature operation life ( HTOL) implementation Track $G$ : Verification, Simulation, and Testing, no. May. 2015.

[7] P. H. I. Teknologi, "Life Tests," in HIE-RD.DQ.WI.207, 2002.

[8] A. Winoto, Mikrokontroller AVR ATmega 8/32/16/8535 dan Pemrogramannya dengan Bahasa C pada WinAVR. 2010.

[9] C. Fahrenheit, "DS18B20 Programmable Resolution 1Wire ${ }^{\circledR}$ Digital Thermometer," pp. 1-27.

[10] L. Fausett, Fundamentals of Neural Network. . 